\title{
The 1787 Drama Dictionary as an Instrument of Enlightenment in Imperial Russia
}

\author{
Polina Zueva \\ Lomonosov Moscow State University, Moscow, Russia
}

\begin{abstract}
The Russian theatre has not been neglected in the studies on theatre history, literary criticism and dramatic arts. The paper attempts to have a look at the 1787 Drama Dictionary, the first theatre reference book published in the country (with a very long Russian title containing 35 words) as a cultural product of the Enlightenment Age produced by its representative. In the introduction to the dictionary the compiler says that the publication would help young people develop a taste for refined entertainment and reject violent leisure activities of the past, enjoy theatre and learn life moral lessons from it. He considers theatre as a powerful means of changing Russian society as has been demanded by the Enlightenment Age. The structural and sociocultural analyses of 1787 Drama Dictionary materials give us an insight into some ways of westernising Russian society through theatre and how this westernisation was reflected in the theatre terminology of the time. I have argued that Russian-European Relationships resulting in the westernisation of Russian theatre theory and practices went hand in hand with the Russian translation-adaptation of Western plays and adaptation of some Western cultural patterns of social thinking and behaviour without rejecting completely the national identity in newly-born Russian dramatic literature.
\end{abstract}

Keywords: theatre history, Russian theatre, the Enlightenment, westernisation, russification, theatre dictionary

\section{Introduction}

In the 18th century theatre influence on Russian public life had greatly expanded, because, on the one hand, Russian amateur theatres blossomed out and, on the other hand, by 1756 Russia had been ready to develop its own national theatre and dramaturgy. The first play of the newly established Russian theatre, as noted in L. M. Starikova's work, took place on February 1, 1757 (Starikova, 1997, p. 82). The following periods are chronologically distinguished in the history of the Russian 18th century theatre ${ }^{1}$ :

- theatre developments \& theatre life in Peter the Great's era (Varneke, 1908; Ignatova, 1914; Vsevolodskij-Gerngross, 1957; Kelly, 1999; Halizeva, 2001);

- theatre and theatre life under Peter the Great's successors Peter II and Anna Ivanovna (Arapov, 1861; Varneke, 1908; Stennik, 1974; etc.);

\footnotetext{
Polina Zueva, Master of Fine Arts, Lomonosov Moscow State University.

1 To tell the truth, the history of Russian Theatre started with Alexey Mikhailovich, father of Peter the Great, who was tsar of Russia from 1645 to 1676 and who introduced theatre at court, but the most significant theatre developments took place in the 18th century when the Russian State Theatre was founded in 1756, theatres for ordinary people (for example, in St. Petersbourg) and private theatres came into existence.
} 
- theatre and theatre life in the era of Empress Elizabeth Petrovna (Arapov, 1861; Brodsky, 1914);

- further theatre and dramaturgy developments during the reign of Catherine II (Arapov, 1861; Varneke, 1914; Evstratov, 2009).

The Russian theatre history has been studied for more than 250 years by many prominent scholars. And among them there are such scholars as Arapov (1861), Varneke (1908), Kalash and Efros (1914), Danilov (1944), Vsevolodskij-Gerngross (1957), Borovsky (1999a; 1999b), Kelly (1999), Halizeva (2001), Schuler (2009) and many others. While examining theatre developments during the 18th century researchers usually refer to different archival data (even rare and antiquarian books), including the first reference theatre publication with 35 words in its title, namely, "Drama Dictionary, or Alphabetic indications of all Russian theater essays and translations, with the names of the aforesaid known authors, translators and composers that when they were presented in the theatres, and where, and at which time printed" (Drammaticheskoi slovar'..., 1778) ${ }^{2}$ that was published in the reign of Catherine the Great. This first theatre reference book appeared in the late 18th century, during the reign of Catherine II. Arapov (1861), Berkov (1959) and Halizeva (2001) have found this archival source very useful for tracing the history of theatre developments in Russia. Though the materials of this dictionary were explored in the course of studying the Russian theatre history (Arapov, 1861), the development of genres of theatre reference books (Halizeva, 2001) or some literature related to the period under consideration, one cannot deny that dictionary materials were mainly used either as a factual basis for literary discussion of 18 th century playwrights' works, or for making conclusions on the 18th century Russian developments in literature, or for trying to solve some historical mysteries about the author of the 1787 Drama Dictionary because the authorship of this dictionary hasn't been yet identified and the question of its authorship is still a highly debatable point.

Even if the 1787 Dictionary was studied as a theater reference book by Halizeva (2001), it hadn't been analysed and viewed by her as a cultural product of a particular historic time period. In her Ph.D. thesis Halizeva (2001) tries to describe some characteristic features of the dictionary mentioned above, but in that description the author does not go beyond:

- some quantitative parameters (number of plays and pages, number of translated and original plays, foreign and Russian) without any attempt to interpret the factual information in the 18th century historical and cultural context;

- simple listing only of the most well-known foreign and Russian playwrights without giving a broader view on all the playwrights whose plays the dictionary compiler found it necessary to include;

- some speculations about who might have been the author of the 1787 drama dictionary;

- some attempts to define - hypothetically, but very narrowly - the purpose of the 1787 Drama Dictionary: "Perhaps, the author was thinking primarily about the descendants, trying to preserve for them all the known facts of the then Russian theatre life" (Halizeva, 2001, p. 9), paying no attention to the Enlightenment spirit that had been developing in Russia in the second half of the eighteenth century, especially during the reign of Catherine the Great, and, accordingly, a didactic function of the dictionary under consideration and how it is reflected in the structure and content of the 1787 Drama Dictionary.

In connection with what has been said above, it seems to be important in this article to give special attention

${ }^{2}$ All cited extracts from the Russian text of the 1787 Drama Dictionary have been translated by P. Zueva. 
to the structure and functions of the 1787 Drama Dictionary as a unique historical and cultural product of the end of the 18th century with clearly distinguishable Enlightenment spirit and aims.

\section{What Does the Extremely Long Title of the 1787 Drama Dictionary Say About Its Content \& Addressee}

If we have a look at the title page of the 1787 Dictionary, we can easily notice that this title tells us a lot about the author's reasons for having compiled this first theatre reference book in Russia. Here is the title: "Drama Dictionary, or Alphabetic indications of all original and translated theater works staged in Russia, with the names of the aforesaid known authors, translators and composers, when these plays were presented in the theatres, and where, and at which time printed. In favor of loving submission of theatre. Moscow, 1787 (A. A. Annenkov Printing house)" (Drammaticheskoi slovar'..., 1787: A4).

As can be seen from this rather long title, the author of the Drama Dictionary intends to share with the reader his knowledge on the theatre works staged in Russia and purposefully selected by him for dictionary entries. He also finds it important to inform the reader which of the theatre works were original plays and in case of foreign plays, the country of their origin and their language, and which of them were plays translated into Russian. Accordingly, he differentiates between playwrights as authors and translators as co-writers. Besides, the author of the dictionary finds it possible to use the word "composers", hinting at the possible presence of music in this or that play.

The title of the Drama Dictionary under consideration also says that the compiler promises to inform the reader about when and where (at what theater) plays were staged on, and even when and where they were published. And if the information about the time and place where a particular play was staged had mostly a factual value, then the information about the time of its publication could have mostly commercial and educational values. This is indirectly confirmed by the analysis of 19th century landowners' library catalogs, for example, the library catalog of the Bryanchaninovs, Vologda noble family (Morozov, 1889), which includes a majority of plays described in the 1787 Drama Dictionary. Sometimes the Dictionary title- "Drama Dictionary" - may be misunderstood by a modern reader, unless he or she refers to the very content of its entries, which includes plays associated with the broader meaning of the term "drama": dictionary entries include reference information, on one hand, about comedies, tragedies and some dramas as specific plays, on the other hand, about operas, ballets, mystery plays and history-bound theatrical performances devoted to the most important events in the Russian history.

The structural analysis of the 1787 Drama Dictionary shows that the dictionary under consideration is an alphabetical catalog-like list of entries on foreign and Russian plays (339 plays all in all), which have been selected by the compiler with his introduction and some additional comments on some plays in dictionary entries. As further seen from the title page, this dictionary has been purposefully and primarily designed for theater lovers and by one of its lovers. This is reported in the author's introductory article and what is of no less interest is that the author emphasizes that though he is not a professional writer as such, but he has done this work mostly for all kids and young people interested in theatre as a form of educational entertainment. Still the author stresses that he hasn't hesitated to publish it, believing that he has done a good job (esteeming a favor for the public) (Drammaticheskoi slovar'..., 1787: A4). 


\section{The 1787 First Theatre Dictionary and Its Specific Mission}

However, in order to understand more deeply for whom this dictionary was compiled, it is necessary to refer to some cultural and historical events that took place in the 18th century, such as:

(1) 1740 was marked by building up an extensive network of amateur (including school and student) theatres in St. Petersburg, Moscow, Kazan, Novgorod, Tver and other cities, that completely lost their original church connection (Arapov, 1861; Danilov, 1944; Kalash \& Efros, 1914).

(2) Democratic (well educated) social stratum took wide initiatives in staging home theatrical performances ${ }^{3}$.

(3) The first state regulation of theatre life in Russia found its expression in the publication of the 1750 legislative act on theatre signed by Emperess Elizabeth Petrovna who gave official permission to put on performances with "Russian comedies" in private houses and recommendations on dress code (Shambinago, 1914).

In the introduction to the Drama Dictionary, the complier pays special attention to the Enlightenment role of theatre. The author emphasizes that

The whole enlightened world knows well how useful and also funny are theater plays that lead not only to well-behaved child-rearing; pleasant sermons without memory burdening during spare time bring fun and pleasant amusement to an older person; when educating young people, theatre works encourage kids' good behavior, clearly revealing the severity of vices, temptation to weaknesses or predilection for credulity, impudence, suspicious shyness, disobedience and many other human faults and weaknesses. (Italicized by P. A. Zueva) (Drammaticheskoi slovar'... 1787: A2)

The dictionary introduction reveals a clear tendency of using theatre as an instrument of Enlightenment, characteristic of the latter half of the 18th century. In other words, at that time theatre had got a new task- to release the human mind from old prejudices and introduce new, enlightened life ideas and true morality. In other words, the text of the dictionary introductions supports some researcher's ideas about the 18th century Russian theatre's role in helping to westernize Russian way of life, changing the people's traditional values and life styles, firstly in the age of Peter the Great (Schuler, 2009), and, finally, in the reign of Catherine the Great (Banham, 1995). Schuler in her book Theatre and Identity in the Emperial Russia argues that Alexei Mikhailovich introduced theatre at court and Peter I mobilized theatre for his war on traditional social and cultural practices of Ancient Rus', but their process was coercive and superficial and relied exclusively upon European models (Schuler, 2009, p. 13). As for Catherine II (the Great), she managed to intensify sociocultural didactic powers of Russian theatre as a social institution, regarding the Russian theatre as a "national school" and herself - the author of historic plays, satirical comedies and comic operas ${ }^{4}$ aimed at her enemies, the freemason

\footnotetext{
${ }^{3}$ In 1749, the servant Kondraty Baykulov submitted an application to the Moscow police with a request to allow him to "play comedies". At the same time in Moscow a group of enthusiasts, led by bureaucrats Hilkovsky and Glushkov, submitted a similar request. In 1755, "a solicitor, Kazan seminary student, trained and moved from Slavonic-Greek-Latin Sciences, Ivan Varfolomeev, Nordinsky son" organized a troupe. The copyist Kochergin, plumber Stepanov, "Ink master of Moscow Printing House" Ivanov and many others submitted applications regarding public performances. In a word, theatre attracts great attention of "wide" artisans (Danilov, 1944, pp. 59-60).

${ }^{4}$ It is interesting to note that, though six plays of Catherine the Great were included in the 1787 Drama Dictionary and highly praised in the dictionary entries, the compiler didn't mention in the entries that it was Catherine II who was the author of these plays. For some reasons, not known yet, the compiler made a decision not to include her name there.
} 
and the theosophies, —as the senior teacher (Banham, 1995, p. 949).

Danilov (1944), developing similar ideas in his book, admits that the 18th century theatre in Russia became not only a place for entertainment, but also a school of reason and morality (Danilov, 1944). Speaking about the Enlightenment times in Russia, one shouldn't forget that they were "dictionary boom" times: It is in the second half of the 18th century that Russian terms related to different spheres of human activity started being studied, systematized and used in reference books. There's quite clear evidence in Vompersky's research (1986) that a number of various dictionaries appeared in the Russian Empire together with the 1787 Drama Dictionary, including such as "Alphabetical register of Russian products, natural and handmade" by M. V. Lomonosov, "Lexicon..." by V. N. Tatishchev, because all kinds of reference books were badly needed in society and by the state for their economic, cultural and political development.

Coming back to the author's introduction to the 1787 Drama Dictionary it should be said that the compiler stresses the idea that theatre as an entertainment seems to be the more appropriate form of leisure in comparison with some pastime activities that were peculiar to Russians before the Enlightenment times. More than that, theatre as a form of entertainment is opposed in the dictionary introduction to some other forms of pastime activities, characteristic of Russia's past:

Who will praise the joy of past centuries? They fought with beasts and with each other until death, considering it to be heroic; fistfights were the best entertainment show, parents brought their children there to be amused; and how to make it possible that in childhood a person wouldn't open his heart to bitterness and violence; until recently even noble women were spectators of this disgrace. (Drammaticheskoi slovar'..., 1787: A3)

The author believes that with the advent of the Enlightenment era, new opportunities are to use theatre as a means of promoting Enlightenment ideas in Russia, and he emphasizes the role not only theatres located in Saint Petersburg and Moscow, but provincial theatres in different Russian regions as well. In his introduction the author draws the reader's attention to the fact that "Fortunately our aforesaid time has changed; the Enlightenment triumphs, good behavior and tenderness are manners; cruelty disappears, violent amusements are left everywhere, no ignorance can be seen even in the remote Russian provinces..." (Drammaticheskoi slovar'..., 1787: A3-A4). In this passage, the author focuses on some important changes in Russian society values and morality. The author strongly emphasizes that

Everyone knows that in ten-year time ... governors who are in charge of supervising remote towns from the capital, thought up with the then nobility to start honorable and useful amusements; we hear about theatres, which were built and are still being built that have quite decent actors. Noble people try to write and translate theater works much to their amusement and general use; it is noticeable that children of noble people and even commoners admire theatrical performance more, than persecution of pigeons, horse hunting or hare baiting... I myself was a witness of this in provinces. (Drammaticheskoi slovar'..., 1787: A4)

In addition to what has been said, it is also interesting to pay attention to the fact that the 18th century theatre as a form of entertainment in Russian Empire didn't $t$ serve only Russian nobility, its public range extended and commoners became an inseparable part of theater-goers.

\section{The 1787 Dictionary Entries Structure and Content}

The 1787 Drama Dictionary describes different types of theatre works including primarily tragedies and 
comedies, and also some dramatic works, comic operas, ballets and musical performances staged in the 18th century Russia. Only after having read the dictionary entries, the reader begins to become aware of the true meaning of the 1787 Drama Dictionary title. In terms of terminology, the Dictionary title uses the first meaning of the "drama" - any theatrical work. Most plays, listed in the dictionary under sonsideration, belong to different varieties of comedies (67.7\% of the total number of plays), or tragedies $(16.7 \%)$.

However, it should be noted that in the author's description of plays some of them are called "drama", for example, the play The Triumph of Love has been named as drama: "THE TRIUMPH OF LOVE. A drama in three acts written in Russian by Vasiliy Levshin, published in Moscow by N. Novikov's University Press in 1787" (Drammaticheskoi slovar'..., 1787, p. 142). In this case, the term "drama" is used to refer to plays without any heroic content (unlike tragedy) usually about middle class people life. The Dictionary of the Russian Language of the XVIII Century (Sorokin, 1984, p. 251) explains, "Drama ... means any kind of theatrical act; therefore, sad comedies refer neither to true comedy, nor to tragedy in its general meaning".

Though the structure of the dictionary entries varies, still it is quite possible to identify some common pieces of information included in the descriptions of theatre works there. Among them are as follows:

- naming the title of any theatre work and its genre;

- indicating whether it is a translation (and from what language) or actually a Russian original play;

- indicating a play authorship (though sometimes the author's name is given only as an acronym), including the author's name, surname, rank and title, if s/he has the latter) and including as well sometimes the translator's name;

- giving information about the printing house, where each of the plays was printed;

- publication year.

For example, "HAMLET. A tragedy by Alexander Sumarokov, that is an imitation of Shakespeare's play, English writer, presented for the first time in early 1750s at the Imperial Theatre in St. Petersburg, printed in Moscow at N. Novikov's University Press in 1781" (Drammaticheskoi slovar'..., 1787, p. 35).

Variable components of dictionary entries may also include additional information about:

(1) the direction of a particular theatre work and audience's opinions and reflections on it;

(2) characteristic features of the translation of this or that play;

(3) the names of famous actors or actresses involved in acting;

(4) moral and ethical values of a particular theatre work;

(5) emotive and expressive information (though rather seldom).

For example, most of Voltaire's works are characterized as the best examples of French playwriting: "ZAIRE. A tragedy of Voltaire considered the best of French drama works..." (Drammaticheskoi slovar'..., 1787, p. 59) or "ALZIRA. A tragedy in five acts, Voltaire's famous play, was staged in Russian by some drama amateurs. The enlightened world knows that this tragedy is the greatest work of the writer..." (Drammaticheskoi slovar'..., 1787, p. 16).

When analyzing the dictionary entries on plays produced by Russian playwrights, it is easy to notice that much praise is given to A. Sumarokov's tragedies, it is vividly seen in the following: "SINAV AND TRUVOR. Sumarokov's tragedy in five acts... There is no need to describe the importance of this famous tragedy, hoping that everyone interested in theatre plays highly respect to it..." (Drammaticheskoi slovar'..., 1787, p. 127) and 
"SEMIRA. A tragedy of A. Sumarokov... The beauty of verses and heroic characters are worthy of respect and immortality of the author. This tragedy was translated into different European languages and was printed many times. Lately Sumarokov's works had been collected and printed in Moscow at N. Novikov's University Press in 1781" (Drammaticheskoi slovar'..., 1787, p. 124).

\section{The Role of Russian-European Relationship in Developing Russian National Theatre}

The sociocultural content analysis of the dictionary under discussion proves that the compiler tried to give a social insight into many plays written mostly by prominent Russian and foreign dramatists playwrights (Ancient Greek, Latin, French, German, Italian, English), though one can also come across a few works written by less known playwrights. The 1787 Drama Dictionary contains theatre information about well-known works by Moliere, Voltaire, Racine, Corneille, Lessing, Goldoni, Destouches, Marivaux, Regnard, Marmontel, Terentius and a number of other less known authors. It is clear from the dictionary analysis that some of the European plays were once staged in German or French or even Latin (at religious school theatres), but most European plays were translated from French, German, Italian, Latin and even Polish ${ }^{5}$.

It is worth adding that according to the opinion of the dictionary compiler, the role of a translator of foreign plays has been as important, as a playwright's job. That was why in his dictionary he gives besides the names of playwrights, the names of translators in most cases as well. Moreover, the description can contain not only their names, but also additional information, such as their social status, their belonging to a particular social stratum/social class and even some evaluation hints on the translation quality of translated works. Many of these translators later became famous Russian playwrights like M. I. Verevkin, Ja. B. Knyazhnin, M. I. Popov. More than that, thanks to the 1787 Drama Dictionary we've learnt that the translations of some Western plays were made by amateur translators, among them were pupils of the Cadet Corps and the Institute of Noble Maidens, students of Moscow State University, actors themselves, military men of that time, family members of landowners and others. And that is a very interesting sociocultural phenomenon when translation theatre works and other pieces of literature was not only a professional activity, a means of introducing Western theatre into the 18th century, but it became one of the dominating literature hobby and a means of stimulating to retranslate Western social ideas expressed in these plays and model cultural patterns of behavior in Russian society (at least in its educated circles). In the 18th century the role of translation as a means of cultural powerful influence on Russian society, especially on the noble elite in terms of its ways of thinking and cultural patterns of behavior, can hardly be overestimated, as Schuler puts it, "In the eighteenth century, a noble elite, which aspired to enter the Western European universe as a social and cultural equal, shaped the art and dramatic literature in Russa" (Schuler, 2009, p. 4). The description of plays written by newly-born 18th century Russian dramatists was included in the entries of the 1787 Drama Dictionary. Among them were the plays written by A. O. Ablesimov, M. I. Verevkin, A. A. Volkov, Ya. B. Knyazhnin, V. P. Kolychev, D. P. Korchakov, M. V. Lomonosov, V. A. Levshin, V. I. Lukin, V. I. Maykov, N. P. Nikolev, M. M. Kheraskov, D. I. Fonvizin (although compared with other playwrights, the latter is represented only by one play- “The Minor"). However, not only were the plays by

\footnotetext{
${ }^{5}$ With Polish plays or it's better to say about plays in the Polish language is a very interesting story. Many of these plays were Western plays translated into Polish, which then had been translated into Russian. Thus, the translation of these plays into Russian was also a somewhat unusual channel of introducing Western theatre works into the 18th century theatre ebnvironment in Russia.
} 
prominent Russian and foreign playwright listed and described in the 1787 Drama Dictionary. The reader may also come across some interesting information on amateur translators of foreign plays and even playwrights who were great theatre lovers and for whom these activities were a kind of a noble hobby. In other words, this dictionary gives us a unique information on writing plays as a part of leisure, a peculiar hobby of the nobility of those times and not only a professional occupation. Among these amateur authors there were army officers and even generals (for example, "Virtue crowned with faithfulness" by M. I. Prokudin-Gorsky), actors (for example, I. Sokolova's plays), and young ladies and gentlemen from nobility circles.

In quantitative terms, the analysis of the ration of Western and Russian plays staged at Russian theatres in the 18th century indicates that the number of foreign plays greatly predominates over the number of Russian plays: the number of foreign plays comes to $55 \%$ of all plays listed and described in the dictionary, meanwhile the number of Russian plays is equal to $37 \%, 6 \%$ of all plays are given without mentioning their authorship and $2 \%$ of all plays are in free translation. In some works on the history of Russian theatre much is said about the Westernisation of Russian society in the 18th century, including the westernisation of theatre theory developed in Russian universities, theatrical experiences, production and performances (Kelly, 1999; Schuler, 2009). But the westernisation of the process of developing national theatre in Russia is only a part of the truth in the developments of theatre and dramatic literature in the country. In the reign of Catherine the Great this westernization went hand in hand with "russification" of Western plays and theatrical experiences in order later on in the 19th century to create in Russia a theatre with distinctive cultural cultural identity. So to say, it was not a one-way but tow-way process. And if in the time of Peter I theatre was forced into the Russian entertainment area, then in the time of Catherine II the Russian-European relationship in the theatreland was coming to that of the dialogue of cultures (in other words, not only Western plays were translated into Russian, but Russian prominent plays were translated from Russian into other languages, for example in French). In this connection, it is important to say that translation became a surprisingly efficient instrument of producing Russian playwrights who were able to follow the best genre samples of Western playwriting, but at the same time to cultivate them in accordance with sociocultural aspects of Russian mentality. The results of the quantitative analysis of the theatre and literary terms used in the 1787 Drama Dictionary seem also to be of interest, if we start thinking about the terminological outcomes of Russian European relationships in the theatreland (see the figure below which gives a quantitative view on the ratio of Western and Russian terms used to describe plays introduced in the dictionary entries). This figure gives us an insight into a terminological landscape of Russian theatre awareness in the 18th century. It clearly shows, on one hand, Latin, French and German origins predominated in the Russian theatre terminology under consideration, but, on the other hand, that Russian own theatre terms were developed and used for describing plays and theatrical experiences. 


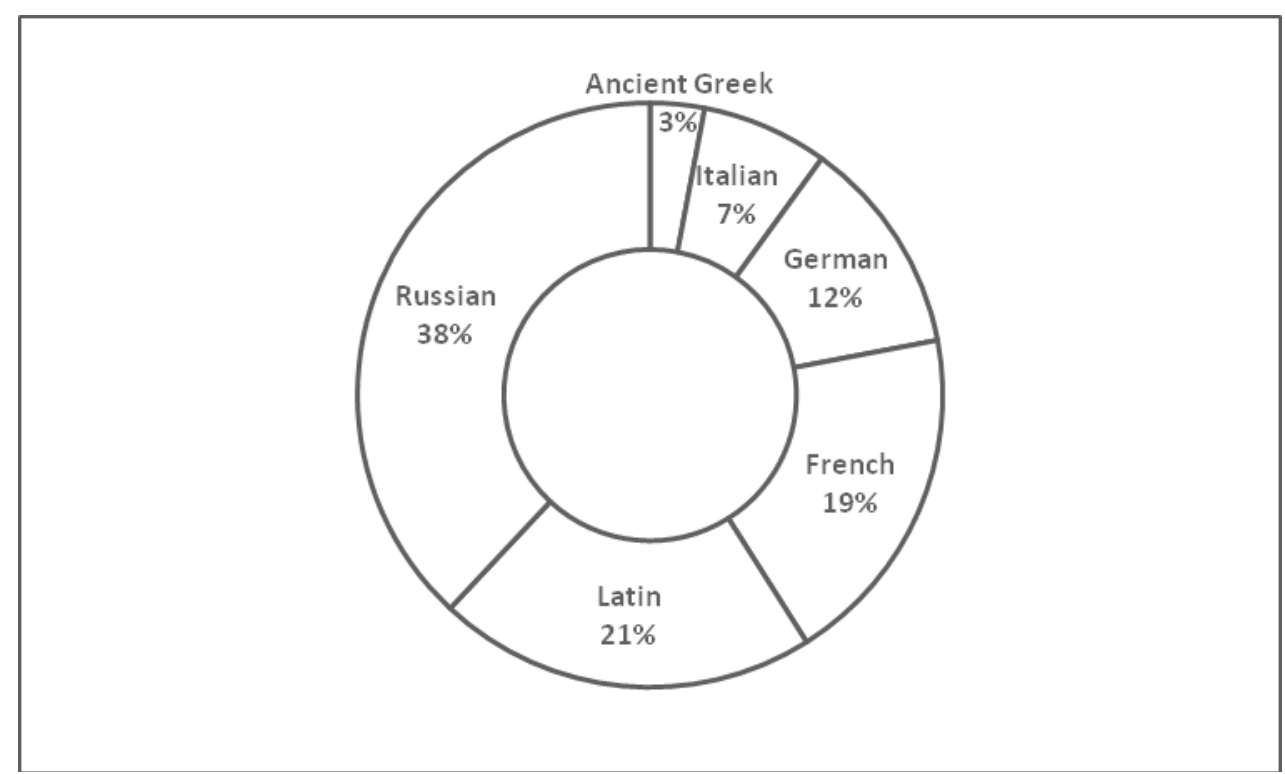

Figure 1. Quantitative view on the ratio of Western and Russian terms.

Russian dramatic literature in the 18th century was a part and parcel of broader achievements in the 18th century Western literature, theory and practice of producing theatre plays, but at the same time Russian theatre tried to find its own identity in the European context. In this connection what is worth mentioning are the following: Cantemir's satires, Trediakovsky's contribution to the reform of Russian verse, Lomonosov's contribution to the further development of the Russian poetic language, Trediakovsky's, Lomonosov's and Sumarokov's dispute on the most debatable questions of drama theory and practice.

As has been said earlier, the Drama Dictionary was published in 1787, but it was certainly compiled much, much earlier. And this should be taken into consideration when analyzing the terminological content of this dictionary as a cultural source of evolutionary theatre developments in Russia in the indicated period.

\section{Conclusion}

To conclude, it should be said that the structural and sociocultural analysis of the Drama Dictionary of 1787 and its entries lets us assume that a archival source helps to create a more specific and detailed picture of theatre developments in Russian Empire in the context of Enlightenment ideas promoted and spread in the country in the second half of the 18th century. And to understand in particular, to which extent Russian-European Relationship, westernisation of Russian theatre theory and practice went hand in hand with the russification of Western plays (when staged in Russia) and adaptation of Western cultural patterns of thinking and behaviour without rejecting national identity in newly-born Russian dramatic literature. Dramatic creativity of theatre professionals and amateurs in Russia has changed the public vision of theatre as a valuable cultural phenomenon and experience. The quantitative analysis of terminology theatre landscape may be a useful tool in analysing cultural relations between countries in a particular century and through centuries.

\section{References}

Arapov, P. A. (1986). Letopis' russkogo teatra (Chronicles of the Russian theatre). St. Petersburg: N. Tiblen and Comp. Printing House. (In Rus) 
Banham, M. (Ed.). (1995) The Cambridge guide to theatre. Cambridge: Cambridge University Press.

Borovsky, V. (1999a). The organisation of the Russian theatre 1645-1763. In R. Leach and V. Borovsky (Eds.), A historyof Russian theatre (pp. 41-56). Cambridge: Cambridge University Press.

Borovsky, V. (1999b). The emergence of the Russian theatre 1763-1800. In R. Leach and V. Borovsky (Eds.), A historyofRussian theatre (pp. 57-85). Cambridge: Cambridge University Press.

Berkov, P. N. (1959). "Drammaticheskij slovar" 1787 goda. In Iz istorii russkih literaturnyh otnoshenij XVIII-XX vekov (Drama Dictionary of 1787. In The history of Russian literary relations of the XVIII-XX-th centuries) (pp. 52-65). Moscow, Leningrad: Izd-vo Akad. nauk SSSR. (In Rus)

Brodsky, L. N. (1914). Teatr v jepohu Elizavety Petrovny. In Istorija russkogo teatra (Theatre in the era of Elizabeth Petrovna. In V. V. Kalash and N. E. Efros (Eds.), A history of the Russian theatre (Vol. 1) (pp. 103-134). Moscow: Book Publishing "Obyedineniye". (In Rus)

Danilov, S. S. (1944). Istorija russkogo dramaticheskogo teatra (A history of the Russian drama theatre). Moscow: Zvezda. (In Rus)

Drammaticheskoi slovar' ili Pokazanï̈a po alfavitu vsekh Rossï̈skikh teatral'nykh sochininenïi, perevodov, s oznachenïem imen izvestnykh sochinitelei, perevodchikov, i slagatelei muzyki, kotoryia kogda byli predstavleny, na teatrakh, i gde, i v kotoroe vremia napechatany. (1787). (Drama Dictionary, or Alphabetic indications of all Russian theater essays and translations, with the names of the aforesaid known authors, translators and composers that when they were presented in the theatres, and where, and at which time published). Moscow: A. A. Annenkov Printing House. (In Rus)

Halizeva, M. V. (2001). Russkie teatral'nye spravochnye izdanija i ih sostaviteli (Russian Theatre Reference Books and Their Compliers) (Ph.D. thesis in Art History, The Russian University of Theatre Arts, Moscow). (In Rus)

Ignatova, S. S. (2014). Teatr Petrovskoi epokhi. In Istoriia russkogo teatra (The theatre of Peter's time. In V. V. Kalash and N. E. Efros (Eds.), A history of the Russian theatre (Vol. 1) (pp. 69-88). Moscow: Book Publishing "Obyedineniye". (In Rus)

Kelly, C. (1999). The origins of the Russian Theatre. In R. Leach and V. Borovsky (Eds.), A history of Russian theatre (pp. 18-40). Cambridge: Cambridge University Press.

Kalash, V. V., \& Efros, N. E. (Eds.). (1914). History of the Russian theatre (Vol. 1). Moscow: Book Publishing "Obyedineniye".

Leach, R., \& Borovsky, V. (Eds.). (1999). History of Russian theatre. Cambridge: Cambridge University Press.

Morozov, P. O. (1889). Istorija russkogo teatra do poloviny XVIII stoletija (The history of the Russian theatre until the half of the XVIII-th century). St Petersburg: V. Demakova Printing House. (In Rus)

Schuler, C. (2009). Theatre and identity in imperial Russia. Jova: University of Jova Press.

Shambinago, S. K. (1914). Teatr vremeni Petra II i Anny Ioannovny. In Istoriia russkogo teatra (Theatre of the time of Peter II and Anna Ivanovna. In V. V. Kalash and N. E. Efros (Eds.), A history of the Russian theatre (Vol. 1) (pp. 89-107). Moscow: Book Publishing "Obyedineniye". (In Rus)

Sorokin, U. S. (Ed.). (1984-1991). Slovar’ russkogo jazyka XVIII veka (Dictionary of the Russian language of the XVIII century). Leningrad: Nauka, Leningrad Branch. Retrieved from http://feb-web.ru/feb/s118/slov-abc/ (In Rus)

Starikova, L. M. (1997). Teatr v Rossii XVIII veka: Opyt dokumental'nogo issledovanija. (Theatre in the XVIII-th century Russia: Experiences in documentary research). Moscow: State Institute of Art Studies, A. A. Bakhrushin State Central Theater Museum. (In Rus)

Varneke, B. V. (1908). Istorija russkogo teatra. Chast’ pervaja: XVII i XVIII veka (A history of the Russian theatre. Part one: XVII and XVIII centuries). Kazan: Printing House of the Imperial University. (In Rus)

Varneke, B. V. Teatr pri Ekaterine II. In Istoriia russkogo teatra (The theatre during the reign of Catherine II. In V. V. Kalash and N. E. Efros (Eds.), A history of the Russian theatre) (Vol. 1) (pp. 115-210). Moscow: Book Publishing "Obyedineniye". (In Rus)

Vompersky, V. P. (1986). Slovari XVIII veka (Dictionaries of the 18-th century). Moscow: "Nauka”. (In Rus)

Vsevolodskij-Gerngross, V. (1957). The Russian theatre. Form its origins to the 18th century. Moscow: Izd-vo AN SSSR. (In Rus) 